\title{
POTENSI EKSTRAK RUMPUT LAUT HIJAU (Bryopsis pennata) SEBAGAI LARVASIDA DALAM MENEKAN ANGKA KEJADIAN DEMAM BERDARAH DENGUE (DBD)
}

\author{
Marhamah $^{1}$, Ismalia Husna² \\ ${ }^{1}$ Jurusan Analis Kesehatan Politeknik Kesehatan Tanjungkarang \\ ${ }^{2}$ Departemen Parasitologi Fakultas Kedokteran Universitas Malahayati
}

[email korespondensi: ismaliahusna.ih@gmail.com]

\begin{abstract}
The Potential of Bropsis pennata Extract as Larvacide in Suppressing Incidence of Dengue Hemorrhagic Fever. Mosquito is one of the vectors that can transmit various diseases such as Dengue Hemorrhagic Fever (DHF). In general, the management of DHF patients in hospitals is supportive and symptomatic, therefore biological control is one of the methods which using to reduce the spread of dengue cases, one of them is the use of green seaweed (Bryopsis pennata) extract. Green seaweed extract can be used to kill Aedes aegypti larvae through morphological destruction, histological changes in the midgut larvae, and disrupt the work of larval organs because it has chemical compounds such as alkaloids, saponins, and steroids which are respiratory poisons and stomach poisons to Aedes aegypti larvae. So that Bryopsis pennata can be developed as larvicide to kill Aedes aegypti larvae and DHF can be eradicated.
\end{abstract}

Keywords: Bropsis pennata, Aedes aegypti, DHF

\begin{abstract}
Abstrak: Potensi Ekstrak Rumput Laut Hijau (Bryopsis Pennata) sebagai Larvasida Dalam Menekan Angka Kejadian Demam Berdarah Dengue (DBD). Nyamuk merupakan salah satu vektor yang dapat menularkan berbagai penyakit seperti Demam Berdarah Dengue (DBD). Pada umumnya penatalaksanaan pasien DBD di rumah sakit bersifat suportif dan simptomatis, karena itu pengendalian biologi merupakan salah satu cara yang digunakan untuk menurunkan angka penyebaran kasus DBD, salah satunya dengan pemanfaatan ekstrak rumput laut hijau (Bryopsis pennata). Ekstrak rumput laut hijau dapat digunakan untuk membunuh larva Aedes aegypti melalui perusakan morfologi, perubahan histologi di bagian midgut larva, dan mengganggu kerja organ larva karena memiliki senyawa kimia seperti alkaloid, saponin, dan steroid yang merupakan racun pernapasan dan racun perut terhadap larva Aedes aegypti. Sehingga B. pennata dapat dikembangkan sebagai larvasida untuk mematikan larva Aedes aegypti dan penyakit DBD dapat diberantas.
\end{abstract}

Kata Kunci: Bropsis pennata, Aedes aegypti, DBD

\section{PENDAHULUAN}

Nyamuk merupakan salah satu vektor yang dapat menularkan berbagai penyakit parasit dan virus seperti malaria, filariasis, Demam Berdarah Dengue (DBD), Japanese B enchepalitis, chikungunya, demam kuning, dan virus zika. Hasil dari berbagai penelitian memperlihatkan nyamuk Anopheles $s p$ merupakan vektor malaria dan filariasis, Culex $s p$ vektor filariasis dan Japanese $B$ Enchepalitis, dan Aedes $s p$ vektor DBD, filariasis, chikungunya, dan virus zika. Vektor tersebut tersebar luas di seluruh dunia, terutama di daerah yang beriklim tropis dan subtropis. Oleh karena itu, vektor nyamuk tersebut sangat penting dalam penularan berbagai penyakit tersebut (Safar, 2009).

$\mathrm{Di}$ Indonesia penyakit yang ditularkan melalui vektor nyamuk tersebut masih merupakan masalah kesehatan masyarakat. Prevalensi malaria di Indonesia $4,5 \%$ dan filariasis 4,7\% (Depkes, 2015). Selain itu prevalensi Japanese $B$ Enchepalitis di Indonesia, khususnya di Kalimantan Barat sebesar $30 \%$ dan di Irian Jaya sebesar 18\% (Sendow et al, 2000). Penyakit DBD diketahui 390 juta kasus per tahun di dunia dengan 96 juta kasus berat dan di prediksi prevalensi DBD 
dunia adalah 3,9 milyar orang yang terkena di 128 negara. Kasus DBD di Asia Tenggara dan Pasifik Barat bahkan melebihi 1,2 juta dan lebih dari 3 juta pada tahun 2013 (Bhatt et al, 2013), dan kasus DBD di Indonesia diketahui 100 juta kasus per tahun (Depkes, 2015).

Karena banyaknya penyakit yang ditularkan oleh nyamuk, makalah ini difokuskan kepada vektor penyakit DBD, yaitu nyamuk Aedes sp karena kasus DBD sering muncul di Indonesia khususnya saat musim pancaroba. Tahun 2014 tercatat penderita DBD di 34 provinsi di Indonesia sebanyak 71.668 orang dan 641 orang diantaranya meninggal dunia, angka tersebut lebih rendah dibandingkan pada tahun 2013 dengan jumlah penderita mencapai 112.511 orang dan 871 orang diantaranya meninggal dunia (Depkes, 2015).

Pada umumnya, penatalaksanaan pasien DBD di rumah sakit bersifat suportif dan simptomatis. Penatalaksanaan ini ditujukan untuk mengganti hilangnya cairan akibat kebocoran plasma dan memberikan terapi substitusi komponen darah jika diperlukan. Pengobatan suportif berupa pemberian cairan intravena dan pengobatan simptomatik yaitu pemberian antipiretik misalnya parasetamol jika suhu $>38^{\circ} \mathrm{C}$. Pada DBD dengan kondisi hemodinamik tidak stabil (derajat 3 dan 4) cairan diberikan secara bolus atau tetesan cepat antara $6-10 \mathrm{mg} / \mathrm{kg}$ berat badan, dan setelah hemodinamik stabil secara bertahap kecepatan cairan dikurangi hingga kondisi benar-benar stabil, namun jika tetap tidak stabil kemungkinan terjadi perdarahan internal dan hal tersebut sering kali menimbulkan kematian, karena itulah angka kematian DBD cukup tinggi (Chen et al, 2009).

Sampai saat ini belum ada obat dan vaksin untuk penyakit DBD, oleh karena itu salah satu pemberantasan penyakit DBD dilakukan dengan pengendalian vektor, Aedes sp. Pengendalian terhadap vektor dapat dilakukan dengan cara pengendalian mekanik, yaitu pengendalian dengan menggunakan alat yang dapat membunuh, menangkap, dan menghalau vektor, seperti menggunakan baju pelindung atau memasang kawat kasa pada jendela. Hal tersebut dapat menghalangi kontak manusia dengan nyamuk. Selain itu, pengendalian fisik, yaitu penggunaan alat fisika untuk pemanasan, pembekuan, penggunaan alat listrik untuk pengadaan angin, dan penyinaran cahaya (Safar, 2009; Depkes RI, 2007).

Pengendalian biologik dapat
dilakukan dengan memperbanyak predator alami bagi vektor seperti beberapa spesies ikan seperti ikan mas (Ciprinus carpio), bakteri (Bacillus thuringiensis), (Rommanomermis iyengari), dan arthropoda (Arrenurus mandaraszi). Selanjutnya, pengendalian genetik dapat dilakukan dengan cara memandulkan nyamuk jantan, namun hal tersebut harus diteliti lebih lanjut karena belum pernah berhasil dilakukan di lapangan (Safar, 2009; Depkes RI, 2007).

Sebagian besar pengendalian nyamuk dilakukan secara kimiawi dengan menggunakan insektisida, yaitu fenitrotion, abate atau temefos, dan malation. Pengendalian tersebut memiliki keuntungan, yaitu dapat dilakukan dengan segera dan mencakup daerah yang luas dengan waktu singkat, misalnya penggunaan fogging (pengasapan) yang dapat membunuh nyamuk dewasa dalam waktu singkat dengan cakupan daerah yang luas. Meskipun demikian, insektisida tersebut menimbulkan pencemaran lingkungan, mengganggu ekosistem, bersifat toksik dan membunuh tanaman tempat perindukan nyamuk, dan resistensi vektor terhadap insektisida seperti adanya mutasi gen serta kemampuan vektor melakukan detoksifikasi (Safar, 2009). Oleh karena itu, diperlukan insektisida alternatif untuk pengendalian populasi nyamuk, yaitu dengan pemanfaatan tanaman.

Berbagai penelitian untuk mengendalikan populasi nyamuk dengan menggunakan insektisida alami, yaitu dari tanaman (herbal). Beberapa spesies yang telah diteliti adalah Lantana camara (tanaman tembelekan), Achyranthes aspera (daun sengketan), Zingiber officinalis (jahe), Ricinus communis (tanaman jarak), Trachyspermum ammi (rempah ajwain), Cassia occidentalis (Chen et al, 2009). Pengendalian ini adalah cara lain yang ditempuh untuk dapat menggantikan pengendalian secara kimiawi yang ternyata memiliki beberapa kerugian. Larvasida alami digunakan untuk membunuh Ae. aegypti pada tahap 
larva sehingga tidak berkembang menjadi nyamuk dewasa. Larvasida alami juga diyakini toksik terhadap serangga, tidak mengganggu lingkungan, dan diharapkan tidak menimbulkan resistensi (Safar, 2009; Depkes RI, 2007).

\section{METODE}

Artikel ini bersifat review sehingga metode yang digunakan adalah pengumpulan data dari penelitianpenelitian yang telah dilakukan.

\section{PEMBAHASAN}

\section{Larva Aedes aegypti}

Larva keluar setelah telur menetas, tetapi hanya setelah telur terkena atau terendam air (Muktar et al, 2016). Larva Ae. aegypti memiliki empat tahapan dalam perkembangannya yang disebut dengan instar. Perkembangan larva dari instar I- IV memerlukan waktu sekitar 5 hari. Larva mengambil makanan dari tempat perindukannya. Toraks larva nyamuk lebih lebar dari kepalanya. Kepalanya dilengkapi dengan

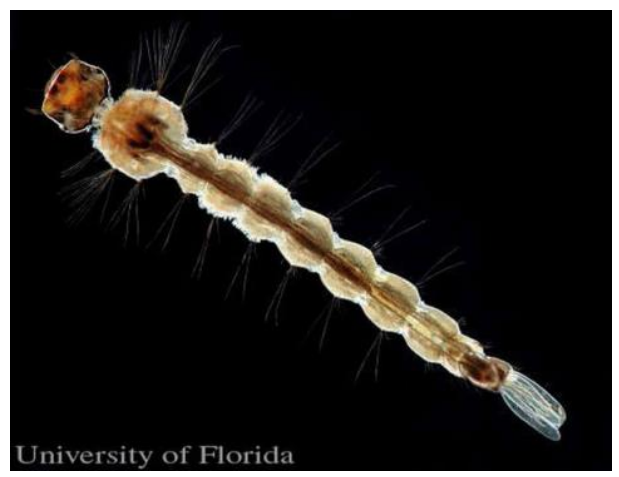

Gambar 1. Larva Ae. aegypti (Zettel \& Philip, 2009)

Perilaku dan Siklus Hidup Ae. aegypti Penularan penyakit dilakukan oleh nyamuk betina $A e$. aegypti, karena hanya nyamuk betina yang menghisap darah. Hal itu dilakukannya untuk memperoleh asupan protein yang diperlukannya untuk memproduksi telur. Pengisapan darah dilakukan dari pagi sampai petang dengan dua puncak waktu yaitu setelah matahari terbit (08.00-10.00) dan sebelum matahari terbenam (15.0017.00). Nyamuk jantan tidak membutuhkan darah, dan memperoleh energi dari nektar bunga ataupun tumbuhan (Djakaria, 2004).

Tempat perindukan Ae. aegypti di daerah asalnya (Afrika) berbeda dengan antenna dan mata majemuk, serta sikat mulut yang menonjol. Abdomen terbagi dalam 10 ruas dan hanya 9 ruas yang jelas, dan ruas terakhir dilengkapi dengan tabung udara (sifon) yang berbentuk silinder (Zettel \& Philip, 2009).

Proses perubahan larva instar I hingga instar IV sebagai berikut (Zettel \& Philip, 2009):

a. Larva instar I : kurang lebih 1 hari, berukuran 1-2 mm, duri-duri (spinae) pada dada belum jelas dan corong pernapasan pada sifon belum jelas

b. Larva instar II : kurang lebih 1-2 hari, berukuran 2,5-3,5 mm, duriduri belum jelas, corong kepala mulai menghitam

c. Larva instar III : kurang lebih 2 hari, berukuran 4-5 mm, duri-duri dada mulai jelas dan corong pernapasan berwarna coklat kehitaman

d. Larva instar IV : kurang lebih 2-3 hari, berukuran 5-6 $\mathrm{mm}$ dengan warna kepala gelap

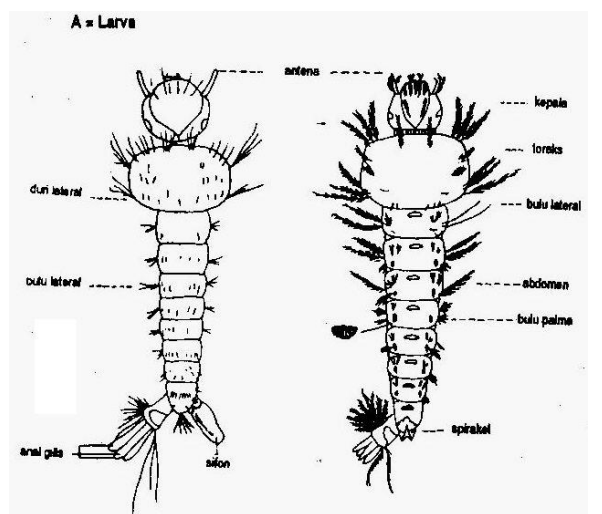

Gambar 2. Morfologi larva Ae. aegypti (Safar, 2009)

di Asia. Nyamuk di Afrika hidup di hutan dan tempat perindukannya pada genangan air di pohon, sedangkan nyamuk di Asia hidup di daerah pemukiman dan tempat perindukannya pada genangan air bersih buatan manusia (man made breeding place). Tempat perindukan $A e$. aegypti dapat dibedakan atas tempat perindukan sementara, permanen, dan alamiah.

Tempat perindukan sementara terdiri dari berbagai macam tempat penampungan air (TPA), termasuk kaleng bekas, ban mobil bekas, pecahan botol, pecahan gelas, talang air, vas bunga, dan tempat yang dapat menampung genangan air bersih. Tempat perindukan 
permanen adalah TPA untuk keperluan rumah tangga seperti bak penampungan air, bak mandi, gentong air. Tempat perindukan alamiah berupa genangan air pada pohon, seperti pohon pisang, pohon kelapa, pohon aren, potongan pohon bambu, dan lubang pohon (Chahaya, 2003).

Nyamuk Ae. aegypti mengalami metamorfosis sempurna. Nyamuk betina meletakkan telur pada permukaan air bersih secara individual, terpisah satu dengan yang lain, dan menempel pada dinding tempat perindukannya. Telur menetas dalam satu sampai dua hari menjadi larva. Perkembangan larva dari instar I-IV memerlukan waktu sekitar lima hari. Setelah itu larva berubah menjadi pupa. Pupa bertahan selama dua hari sebelum akhirnya nyamuk dewasa keluar dari pupa (Depkes RI, 2007).

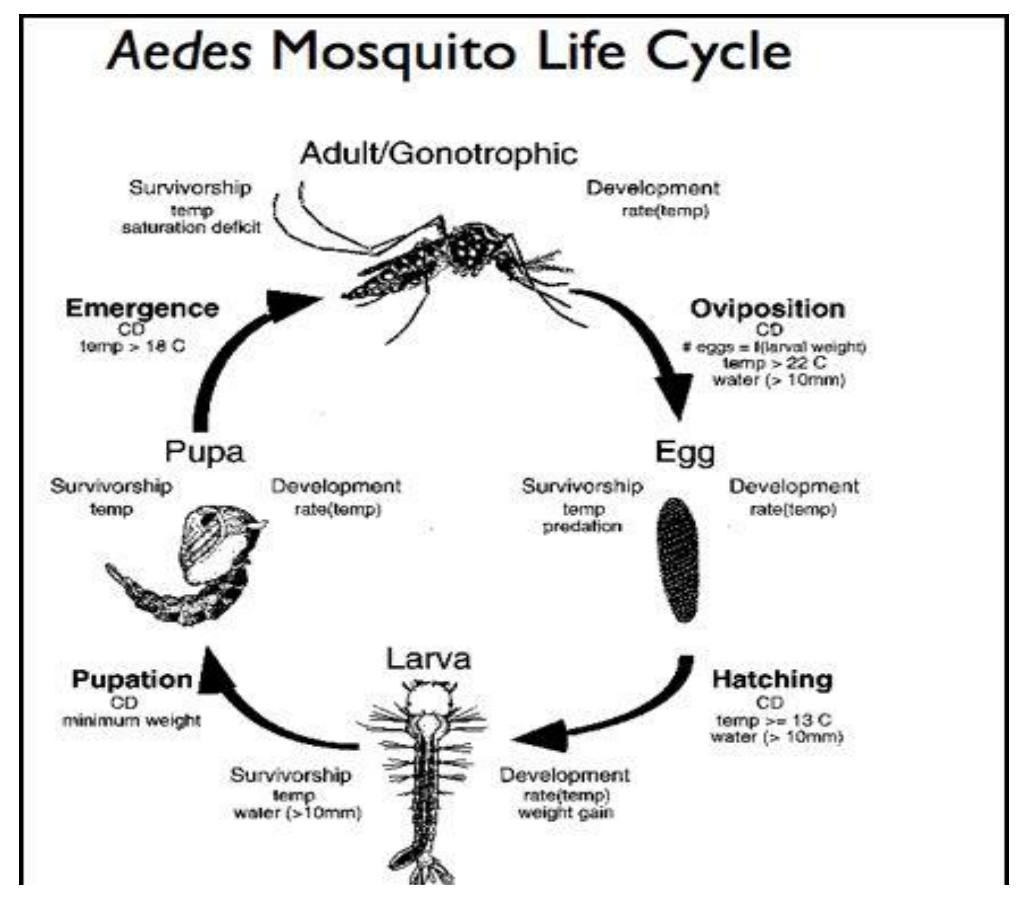

Gambar 3. Siklus Hidup Ae. aegypti (Muktar et al, 2016).

\section{Insektisida}

\section{Insektisida Kimia}

Insektisida yang mengandung senyawa kimia saat ini merupakan insektisida yang banyak digunakan karena memiliki efektifitas dalam membunuh serangga seperti nyamuk, meskipun telah banyak penelitian yang menyatakan bahwa insektisida kimia dapat merusak lingkungan dan banyak kasus resistensi terhadap beberapa insektisida kimia (Staf Pengajar Departemen Parasitologi FKUI, 2013). Insektisida berbahan kimia diantaranya adalah fenitrotion 40WP yang termasuk golongan organofosfat dan bersifat sedikit menguap, karena itu penggunaannya dengan semprotan ke dinding rumah. Temefos atau abate merupakan insektisida yang tergolong oraganofosfat yang berbentuk granula dan biasanya digunakan untuk pengendalian larva Ae. aegypti di tempat penampungan air. Malation 96\% termasuk golongan organofosfat yang berbentuk larutan berwarna tengguli, berbau, dan sulit larut dalam air, biasa digunakan untuk memberantas nyamuk dewasa Ae. aegypti dengan cara pengasapan (fogging) (Staf Pengajar Departemen Parasitologi FKUI, 2013).

\section{Insektisida Herbal}

Insektisida herbal merupakan insektisida yang berasal dari tanaman dengan efek toksik terhadap serangga tetapi tidak toksik terhadap hewan bukan target dan tidak merusak lingkungan. Insektisida yang berasal dari tanaman ini merupakan alternatif yang diambil untuk memberantas serangga seperti nyamuk dan mengurangi risiko resistensi (Kumar et al, 2012).

Beberapa spesies yang telah diteliti adalah Lantana camara (tanaman tembelekan), Achyranthes aspera (daun 
sengketan), Zingiber officinalis (jahe), Ricinus communis (tanaman jarak), Trachyspermum ammi (rempah ajwain), Cassia occidentalis, dan beberapa spesies rumput laut (Kumar et al, 2012). Rumput laut hijau seperti Bryopsis pennata dan rumput laut coklat seperti Padina australis dan Sargassum binderi telah diteliti memiliki efektivitas terhadap penurunan fungsi bahkan kerusakan organ larva Aedes sp (Yu et al, 2015).

\section{Pengukuran efektivitas larvasida Bioassay}

Bioassay dilakukan dengan menyiapkan ekstrak dengan ulangan 4-5 kali dan kemudian dilihat angka mortalitas larva setelah terpajan oleh ekstrak larvasida selama 24-48 jam (WHO, 2005).

\section{Perubahan morfologi larva}

Morfologi larva diobservasi setelah pemberian ekstrak dan dilihat apakah terjadi perubahan pada morfologi larva tersebut. Perubahan morfologi yang mungkin terjadi adalah kerusakan papillae anal, distorsi tubuh, gelapnya tubuh, dan pucatnya tubuh larva (Yu et al, 2015).

\section{Kelainan histopatologi larva}

Studi untuk histolopatologi pada pemberian ekstrak terhadap larva adalah melihat anterior dan posterior midgut dari larva, biasanya yang terjadi adalah adanya vesikel dengan berbagai ukuran, kerusakan mikrovili, dan menggembungnya sel (Yu et al, 2015).

\section{Efek hambat ekstrak terhadap perkembangan larva}

Ekstrak larvasida yang diberikan terhadap larva selalu diharapkan dapat menghambat pertumbuhan dan perkembangan larva menuju dewasa. Suatu larvasida dapat dikatakan menghambat pertumbuhan dan perkembangan larva jika semakin lamanya larva berkembang menjadi pupa, atau bahkan tidak dapat berkembang menjadi pupa, sehingga stadium dewasa tidak terbentuk dan pada akhirnya larva tersebut mengalami kematian (Yu et al, 2015).

\section{Bryopsis pennata}

Bryopsis pennata merupakan rumput laut hijau dengan talus filament berwarna hijau gelap yang mengkilap dan berbentuk seperti bulu (Yu et al, 2015). B. pennata tersebar luas di daerah tropis. $B$. pennata memiliki talus berwarna hijau dengan cabang yang tidak beraturan terutama di bagian aksis dan membentuk tumpukan serta menempel pada batu karang atau batu koral. Rumput laut ini telah diketahui memiliki aktivitas antimikroba terhadap bakteri patogen dan protista laut. Telah dilaporkan pula bahwa $B$. pennata memiliki efek antifeedant terhadap larva ngengat Hyblaea puera dan dapat menurunkan protein dan lemak pada larva tersebut (Yu et al, 2015).

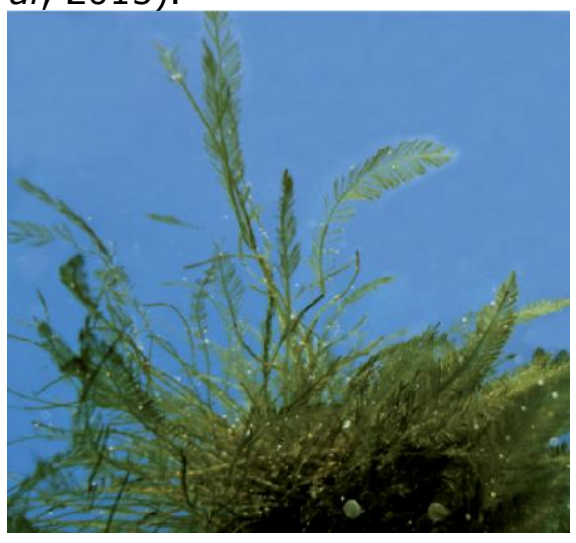

\section{Gambar 4. Morfologi Bryopsis pennata (Bitar, 2017)}

\begin{abstract}
B. pennata memiliki metabolit sekunder bioaktif yang unik dan dilaporkan pula memiliki efek mosquitocidal. Yu et al (2015) melaporkan bahwa terdapat 30 spesies rumput laut yang memiliki aktivitas
\end{abstract}

larvasida pada ekstrak dan komponennya, hal tersebut dapat dijadikan sebagai penelitian lanjutan mengenai obat, insektida, dan program kontrol nyamuk yang nantinya dapat digunakan untuk mencegah dan 
menghindarkan suatu populasi dari penyakit yang disebabkan vektor nyamuk.

Senyawa kimia yang terkandung dalam $B$. pennata diantaranya adalah alkaloid, saponin, steroid, dan terpenoid. Alkaloid dan terpenoid dapat berfungsi sebagai larvasida botani. Alkaloid dengan

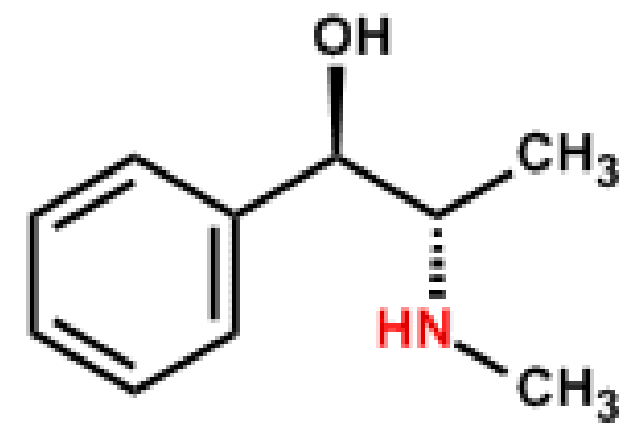

Gambar 5. Struktur alkaloid

Saponin adalah senyawa metabolit sekunder yang dihasilkan oleh spesies tanaman, terutama tanaman dikotil, dan berperan sebagai bagian dari sistem pertahanan tanaman. Saponin diketahui memiliki efek anti serangga, karena dapat menurunkan aktivitas enzim pencernaan dan penyerapan makanan. Saponin juga dapat mengikat sterol bebas dalam pencernaan makanan, dimana sterol berperan sebagai prekursor hormon edikson, sehingga dengan menurunnya jumlah sterol bebas akan mengganggu proses pergantian kulit pada serangga (molting). Tanaman yang mengandung struktur indol seperti strikhnin dan quinine yang terasa pahit merupakan senyawa yang berfungsi sebagai repelen serangga (Mardiana et al, 2009). Terpenoid merupakan senyawa pertahanan bagi tanaman dan bersifat toksik dan menghambat makan serangga (Yanuar, 2009).

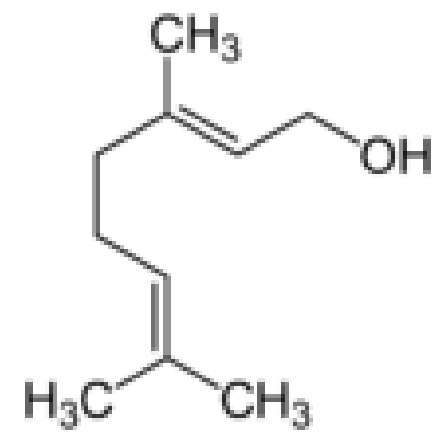

\section{Gambar 6. Struktur terpenoid}

saponin biasanya digunakan sebagai sabun untuk mencuci. Bahan sabun tanpa dicampur apapun dapat berfungsi sebagai larvasida. Pengaruh sabun dapat terlihat pada gangguan fisik pada tubuh serangga bagian luar (kutikula), yaitu dapat mencuci lapisan lilin yang melindungi tubuh serangga dan menyebabkan kematian karena serangga akan kehilangan banyak cairan tubuh. Saponin juga dapat masuk melalui organ pernapasan dan menyebabkan membran sel rusak dan proses metabolisme terganggu (Gunawan, 2009).

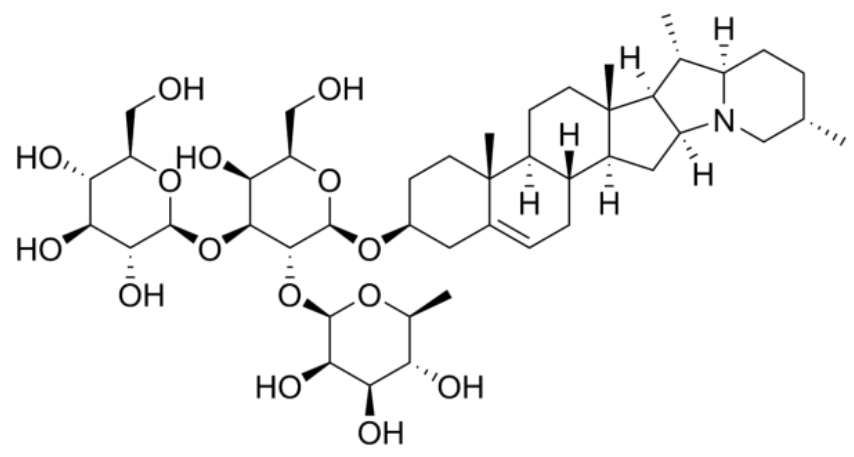

Gambar 7. Struktur saponin

\begin{abstract}
Sedangkan steroid merupakan hormon pertumbuhan yang mempengaruhi pergantian kulit yaitu perubahan stadium dari larva ke pupa dan dari pupa ke dewasa, dengan adanya
\end{abstract}

penambahan steroid yang berasal dari luar akan berpengaruh pada penebalan dinding sel kitin pada tubuh sehingga nyamuk menjadi abnormal (Mardiana et al, 2009). 


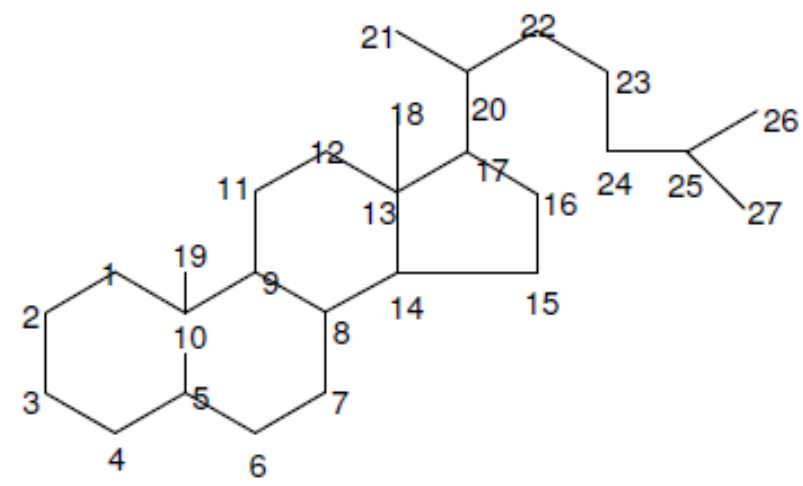

Gambar 8. Struktur dasar steroid

\section{Aktivitas Larvasida B. pennata}

B. pennata diketahui memiliki efek larvasida yang cukup efektif yaitu pada ekstraksi menggunakan pelarut kloroform (Yu et al, 2015).

Tabel 1. Aktivitas larvasida dari B. pennata terhadap Ae. aegypti

\begin{tabular}{ccccc}
\hline Mosquito & Extract & LC $_{\mathbf{5 0}}(\boldsymbol{\mu} \mathbf{g} / \mathbf{m L})(\mathbf{9 5 \%} \mathbf{C L})$ & Slope $( \pm$ SE) & $\boldsymbol{X}^{2}$ \\
\hline & $n$-Hexane & $912.86(821.04-1095.18)$ & $5.25(0.85)$ & 1.12 \\
& Chloroform * & $92.72(82.40-102.85)$ & $3.01(0.31)$ & 3.14 \\
Aedes aegypti & Methanol & $156.97(133.54-179.46)$ & $2.57(0.25)$ & 1.47 \\
& Aqueous & $591.77(528.19-692.70)$ & $3.78(0.49)$ & 0.21 \\
& Abate $^{\circledR} 1.1 \mathrm{G}$ & $0.07(0.06-0.08)$ & $3.21(0.21)$ & 0.90 \\
\hline
\end{tabular}

Pada penelitian yang dilakukan Yu et al (2015), ekstrak $B$. pennata juga memiliki aktivitas adultisida terhadap Aedes $s p$ dan pada penelitian tersebut juga terlihat bahwa ekstrak $B$. pennata dengan pelarut kloroform memperlihatkan aktivitas yang paling baik.

Tabel 2. Aktivitas adultisida B. pennata terhadap nyamuk betina Ae. aegypti dan Ae. albopictus

\begin{tabular}{ccccc}
\hline Mosquito & Extract & $\left.\mathbf{L C}_{\mathbf{5 0}}\left(\mathbf{m g} / \mathbf{c m}^{\mathbf{2}}\right) \mathbf{( 9 5 \%} \mathbf{C L}\right)$ & Slope $( \pm \mathbf{S E})$ & $\boldsymbol{X}^{\mathbf{2}}$ \\
\hline & Hexane & $233.55(200.34-294.34)$ & $2.34(0.90)$ & 1.73 \\
& Chloroform * & $73.49(64.89-85.34)$ & $3.72(0.81)$ & 2.35 \\
Aedes aegypti & Methanol & $86.48(76.76-97.42)$ & $1.14(0.05)$ & 0.99 \\
& Aqueous & $523.82(452.56-559.23)$ & $1.34(0.72)$ & 1.45 \\
& Malathion & $0.01(0.005-0.02)$ & $1.785(0.04)$ & 0.96 \\
\hline & Hexane & $434.32(380.45-480.21)$ & $3.45(0.82)$ & 1.93 \\
& Chloroform * & $100.32(83.78-163.48)$ & $1.39(1.56)$ & 1.34 \\
& Methanol & $156.34(150.10-162.80)$ & $1.41(0.27)$ & 0.99 \\
& Aqueous & $689.39(602.34-723.43)$ & $2.34(2.36)$ & 2.12 \\
& Malathion & $0.015(0.009-0.021)$ & $1.423(0.03)$ & 0.98 \\
\hline
\end{tabular}

Pada Tabel 1 dan 2 memperlihatkan ektrak $B$. pennata diujikan terhadap Aedes $s p$ dengan berbagai pelarut. Dengan pelarut kloroform, ektrak B. pennata menunjukkan aktivitas larvasida tertinggi dibanding dengan pelarut lain. Hal tersebut disebabkan karena kloroform dapat melarutkan senyawa lipid. Selain itu, kloroform merupakan pelarut yang 
biasa digunakan pada farmasi industri diantaranya dalam pembuatan pestisida dan kloroform juga merupakan pelarut yang cocok untuk tanaman yang mengandung alkaloid (Yu et al, 2015).
Pengaruh ekstrak $B$. pennata terhadap morfologi Ae. aegypti dapat dilihat pada Gambar 9 sebagai berikut.
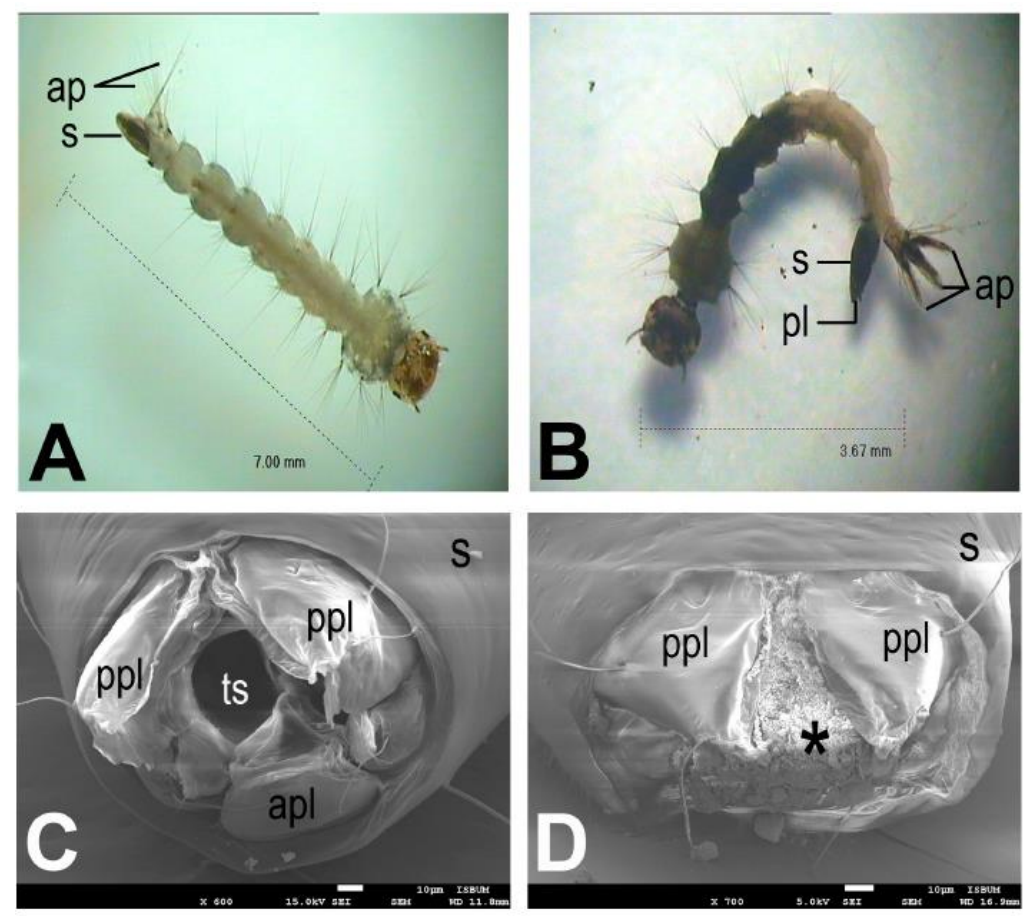

\section{Gambar 9. Morfologi larva sebelum dan sesudah pemberian ekstrak B. pennata (Yu et al, 2015).}

Pada Gambar 9 terlihat bahwa gambar (A) merupakan kontrol negatif larva dan gambar (B) sesudah larva diberikan ekstrak dan terlihat tubuh serta papilla anal menjadi berwarna hitam, sedangkan gambar (C) merupakan gambaran spirakel larva kontrol dan gambar (D) memperlihatkan spirakel larva yang tidak lengkap dan rusak. Hal tersebut dikarenakan adanya senyawa kimia yaitu alkaloid, saponin, dan steroid (Yu et al, 2015).

Senyawa-senyawa kimia tersebut diduga mempengaruhi perkembangan larva dan dapat meracuni larva sehingga pertumbuhan larva menjadi tidak sempurna dan mengakibatkan kematian.
Pada gambar B, diduga ekstrak mempengaruhi sistem pencernaan larva sehingga larva menghitam seperti terbakar dan menghitamnya papilla anal berarti berubahnya struktur sehingga memicu disfungsi organ pada larva dan menyebabkan gangguan osmosis serta regulasi ion yang mengakibatkan ketidakseimbangan homeostatis, sedangkan pada gambar D, ekstrak merubah dan merusak struktur spirakel yang dapat mempengaruhi sistem pernapasan larva sehingga memicu kematian larva karena larva tidak mampu bernapas dengan baik (Yu et al, 2015). 

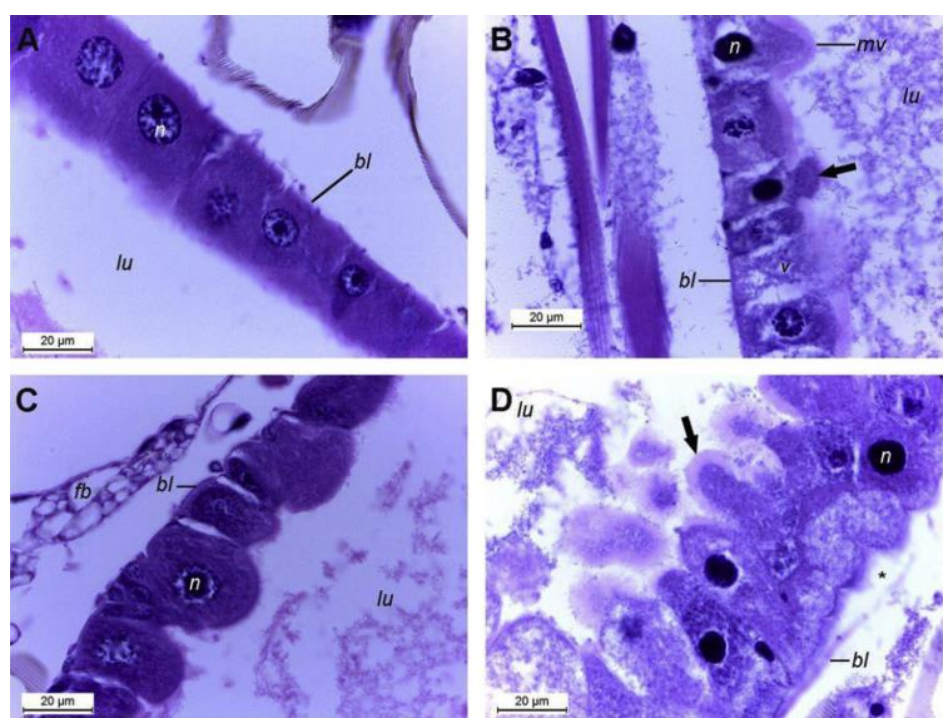

\section{Gambar 10. Histologi larva sebelum dan sesudah pemberian ekstrak S. binderi (Yu et al, 2015).}

Pada penelitian yang dilakukan Yu et al (2015) juga memberikan gambaran histologi larva Ae. aegypti sebelum dan sesudah pemberian ekstrak Sargassum binderi yang juga memiliki senyawa terpenoid seperti $B$. pennata, terlihat pada gambar 10 (A) merupakan sel epitel anterior midgut pada larva normal, (B) sel epitel anterior midgut larva setelah pemberian ekstrak dengan vacuolization dengan tonjolan apikal, (C) merupakan sel posterior midgut larva kontrol, dan (D) sel posterior midgut larva setelah pemberian ekstrak yang menunjukkan adanya tonjolan dari apikal ke lumen dan (*) sel terlepas dari basal lamina (Yu et al, 2015).

Midgut pada larva berperan dalam sekresi enzim degradatif dan penyerapan nutrient. Allelochemical atau senyawa kimia pada tanaman yang toksik terutama pada larva terbukti merusak sel epitel usus dan menurunkan pertahanan pada larva, sehingga pada pemberian ekstrak rumput laut terhadap larva Aedes $s p$ mengganggu fungsi midgut dan menyebabkan kematian pada larva (Yu et al, 2015).

Berdasarkan hal-hal tersebut, ekstrak B. pennata dapat dikategorikan sebagai racun pernapasan dan racun perut. Racun pernapasan merupakan racun yang dapat masuk melalui sistem pernapasan. Pada larva yang diberikan ekstrak B. pennata, struktur papil analnya berubah sehingga hal tersebut dikembangkan sebagai larvasida untuk mematikan larva Aedes aegypti dan penyakit DBD dapat diberantas. dapat berakibat masuknya air atau medium ke dalam trakea melalui spirakel dan membahayakan sistem respirasi lalu menyebabkan kematian pada larva. Sedangkan racun perut masuk melalui makanan lalu meracuni lambung dan mengganggu sistem pencernaan larva yang memiliki peran penting dalam sekresi dari enzim pencernaan dan penyerapan nutrien bagi larva, sehingga jika tidak berfungsi sebagaimana mestinya maka dapat menyebabkan kematian pada larva karena tidak dapat menyerap makanan dengan baik (Yu et al, 2015).

\section{KESIMPULAN}

Pengendalian biologi dengan menggunakan larvasida alami dipilih karena diyakini toksik terhadap serangga, tidak mengganggu lingkungan, dan diharapkan tidak menimbulkan resistensi. Salah satu tanaman yang digunakan adalah spesies rumput laut, Bryopsis pennata.

B. pennata memiliki pengaruh terhadap kematian larva Aedes aegypti karena memiliki senyawa kimia seperti alkaloid, saponin, dan steroid yang merupakan racun pernapasan dan racun perut terhadap larva Aedes aegypti, sehingga merubah morfologi dan mengganggu kerja organ larva dan mengganggu sistem pencernaan melalui midgut larva sehingga terjadi kematian larva, karena itulah $B$. pennata dapat 


\section{SARAN}

Perlu dilakukan penelitian lebih lanjut untuk menguji aktivitas larvasida

\section{DAFTAR PUSTAKA}

Bitar, G., Ramos-Esplá, A.A., Ocaňa, O., Sghaier, Y.R., Forcada, A., Valle, C., Shaer, H.E., and Verlaque, M. (2017). The Introduced Marine Macroflora of Lebanon and Its Distribution on the Levantine Coast. Mediterranean Marine Science

Bhatt, S., Gething, P. W., Brady, O. J., Messina, J. P., Farlow, A. W., Moyes, C.L., et.al. (2013). The global distribution and burden of dengue. Nature 496:504-507.

Chahaya, I. (2003). Pemberantasan Vektor Demam Berdarah di Indonesia. Medan: USU digital library.

Chen, K., Herdiman, T.P., Robert, S. (2009). Diagnosis dan Terapi Cairan pada Demam Berdarah Dengue. Medicinus 22(1).

Depkes. (2015). Demam Berdarah Dengue.

http://www.depkes.go.id/article/v iew/15011700003/demam-

berdarah-biasanya-mulaimeningkat-di-januari.html.

Depkes RI. (2007). Nyamuk Vampir Mini yang Mematikan dalam Inspirasi dan Ide Litbangkes P2B2 Volume 2. Ciamis: Badan Penelitian dan Pengembangan Kesehatan Loka Litbang Pemberantasan Penyakit Bersumber Binatang.

Djakaria, S. (2004). Pendahuluan

Entomologi: Parasitologi

Kedokteran Edisi ke-3. Jakarta:Fakultas Kedokteran Universitas Indonesia.

Djakaria, S. (2004). Vektor Penyakit Virus, Riketsia, Spiroketa dan Bakteri. Dalam: Srisasi, G., Herry, D.I., Wita, P. Parasitologi Kedokteran Edisi Ketiga. Jakarta: Balai Penerbit FKUI.

Gunawan, E. (2009). Efek Potensial Larvasida Kombinasi Ekstrak Daun Kemangi (Ocimum sanctum Linn) dan Biji Jarak (Ricinus communis Linn) Terhadap Aedes aegypti. [Skripsi]. Surakarta: Universitas Sebelas Maret.
B. pennata terhadap larva Ae. aegypti di lapangan dan pengujian ekstrak terhadap nyamuk dewasa Ae. aegypti dalam bentuk gel atau lotion.

Kumar, S., Naim, W., Monika, M., Radhika, W. (2012). Evaluation of 15 Local Plant Species as Larvicidal Agents Against an Indian Strain of Dengue Fever Mosquito, Aedes aegypti L. (Diptera: Culicidae). Front Physiol 3 (104).

Mardiana, Supraptini, Nunik, S.A. (2009). Datura metel Linnaeus sebagai Insektisida dan Larvasida Botani Serta Bahan Baku Obat Tradisional. Media Penelitan dan Pengembangan Kesehatan 19.

Muktar, Y., Nateneal, T., and Abnet, S. (2016). Aedes aegypti as a Vector of Flavivirus. Journal of Tropical Diseases 4(5).

Safar, R. (2009). Parasitologi

Kedokteran: Protozoologi, Helmintologi, Entomologi. Bandung: CV. Yrama Widya.

Sendow, I. S., Bahri, A., dan Sarosa. (2000). Prevalensi Japanese-BEncephalitis pada Berbagai Spesies di Indonesia. JITV 5 (1).

Staf Pengajar Departemen Parasitologi FKUI Jakarta. (2013). Buku Ajar Parasitologi Kedokteran. Jakarta: Badan Penerbit FKUI Jakarta.

WHO. (2005). Guidelines for Laboratory and Field Testing of Mosquito Larvicides. Geneva: World Health Organization.

Yanuar, F., P. (2009). Indeks

Pertumbuhan Larva Aedes aegypti L. yang Terdedah Dalam Eksrak Air Kulit Jengkol (Pithecellobium lobatum). Aspirator 1 (2): 81-86.

Yu K.X., Ching L.W., Rohani A., Ibrahim J. (2015). Larvicidal Activity, Inhibition Effect on Development, Histopathological Alteration and Morphological Aberration Induced by Seaweed Extract in Aedes aegypti (Diptera: Culicidae). Asian Pacific Journal of Tropical Medicine 8(12): 1006-1012.

Yu K.X., Ching L.W., Rohani A., Ibrahim J. (2015). Mosquitoidal and Oviposition Repellent Activities of the Extract of Seaweed Bryopsis pennata on Aedes aegypti and 
Aedes albopictus. Molecules 20

(8); 14082-14102.

Zettel, C and Phillip, K. (2009). Yellow

Fever Mosquito Aedes aegypti

(Linneus) (Insecta: Diptera:

Culicidae). EDIS. 